\title{
Civicness and the Third Sector: Introduction
}

\author{
Paul Dekker · Adalbert Evers
}

Published online: 7 July 2009

(C) The Author(s) 2009. This article is published with open access at Springerlink.com

Civility has not been a big topic in the expanding research on civil society during the last two decades. This could well reflect a more general reluctance in the modern social sciences to address moral questions and normative considerations in the investigations. One clear exception is the "global civil society" debate, which is concerned with a more normative and political concept than civil society as such (and which is more a subject for social and political theorists than for empirical researchers). Civil or global civil society has, in recent years, been well-discussed in various papers in this journal. ${ }^{1}$ As regards the concept in its national applications, civility has primarily been an implicit orientation. Articles focus on the presentation of the interests of deprived groups, on broadening social and political participation, on the effects of social participation on political involvement, or on the possibilities for controlling and influencing government policies. Authors may state that broad involvement is "generally considered" to be an important element of democracy, etc., but normative and political issues are seldom addressed explicitly.

In this special issue of Voluntas we do not focus on global civil society, or on pressure and interest groups. Our interest is in civility and its impact in society as a whole-since that impact manifests itself on such different levels as personal

\footnotetext{
1 See, for example, Taylor (2002), where Taylor worries about the tendency to eschew normative questions and asks how far research on global civil society is "going to get within a normative vacuum?" (p. 341). Anheier (2007), replied "Not much further" (p. 10). And Munck (2006) has made a plea to bring politics back into the "normative conception of [global civil society] based on Habermasian communicative rationality" (p. 331).
}

\section{P. Dekker $(\square)$}

Tilburg University and The Netherlands Institute for Social Research/SCP, Postbus 16164, 2500 BD Den Haag, The Netherlands e-mail: p.dekker@scp.nl

\section{A. Evers}

Justus-Liebig-Universität, Giessen, FB 09 Bismarckstr. 37, 35390 Giessen, Germany e-mail: adalbert.evers@uni-giessen.de 
interrelations and public action, in private realms, community life, and politics. In this special issue we focus on social service systems because they capture this broad and differentiated landscape well, extending from the small-scale interactions of personal services over issues of civil intra- and inter-organizational behaviour, to governance issues.

In particular, we are interested in the relationships between institutional structures and the norms and values that guide actors. We consider civility as something that is primarily embodied in people's attitudes and behaviour, both private and public, and define civicness as the capacity of institutions, organizations, and procedures to stimulate, reproduce, and cultivate civility. This idea of civicness has been a starting point for all the authors in this special issue, but they each develop their own ideas of civicness and civility. ${ }^{2}$

In the first paper, Paul Dekker starts with diverse concepts of civility and the expectations of its advancement by civil society as the societal sphere in which voluntary associations are dominant. Dekker finds mixed evidence for the civicness of the pure civil society and focuses on new phenomena in the margins and crossing the boundaries of this sphere for more promising developments.

Adalbert Evers goes further in that direction, arguing that the third sector does not have a natural prior impact when it comes to creating and cultivating civicness and civility. Hence, when illustrating the ways in which these two items unfold and change in different concepts of social services, the role of third sector organizations is just one factor to be considered; state-society relationships in governance, images of the users and professionals and of service interactions are also seen as key factors that shape notions of civicness and civility.

In the third paper, Taco Brandsen focuses on organizations in the field of social services and places professional-manager relationships in the civicness perspective. Since both professions represent different mixes of competing organizational values, there is more potential for internal conflict. The civic quality of an organization is important in dealing with the tensions that arise, not only as a means of coordinating social action within an organization, but also as a link to broader social developments in society.

Next, in Bernard Enjolras' contribution we move from organizations to governance regimes in welfare and social services. Here again, civicness is understood as something that flows from and is likewise supported by partnershipbased governance regimes as opposed to market-based or competitive governance. Modernization processes within the field of social services in Europe develop in the critical area between these two radically different regulative conceptions.

\footnotetext{
2 The concept of civicness has been developed in Work package 15 of the CINEFOGO (CIvil society and NEw FOrms of GOvernance) European network of excellence, which was subsidized by the European Union between 2004 and 2009. With the exception of the contribution of Nina Eliasoph, the papers in this issue have been presented at earlier in meetings of this network and in a panel at the ISTR conference in Barcelona, Spain in 2008. We thank the participants at these meetings for their comments, as well as Thomas Boje and his team at Roskilde University for organizing CINEFOGO, and the European Commission for its financial support of the network. We organized the work package together with Taco Brandsen and with the support of Benjamin Ewert. A more complete collection of results will be edited by Brandsen, Dekker, and Evers and published by NOMOS Verlag at the end of 2009.
} 
In the fifth and final paper, by Nina Eliasoph, we return to the benefits and drawbacks of voluntary involvement for civility and civicness, but this time in the context of empowerment projects in the United States rather than in the European setting. Eliasoph underlines the presence of state interventions, as well as of broader cultural orientations as they unfold in the public sphere within contemporary forms of volunteering in empowerment projects, and raises questions about their civic character.

The reader will notice that not only do the cases vary-whether they be in the field of social services, social projects, organizations, or forms of governance-but that the civil and civic focal points do so as well. Yet there is an overlapping consensus on the need to temper expectations with regard to the impact of the third sector. Most of its organizations undoubtedly contribute to making society more civic. But civicness and civility, and their impact for a civilized society at large, have to be seen as by-products of complex interactions that cut across sectors. In order to make such interactions and exchanges possible, they need democratic forms of governance and public spaces. And when it comes to welfare and social services, professional discourses, again crossing sectoral boundaries, are an additional important factor.

We hope that this special issue, with its common concerns and variety of perspectives, concepts, and empirical phenomena, may stimulate further discussions and research on the civil of civil society.

Open Access This article is distributed under the terms of the Creative Commons Attribution Noncommercial License which permits any noncommercial use, distribution, and reproduction in any medium, provided the original author(s) and source are credited.

\section{References}

Taylor R. (2002). Interpreting global civil society. Voluntas, 13(4), 339-347.

Anheier H. (2007). Reflections on the concept and measurement of global civil society. Voluntas, 18(1), $1-15$.

Munck R. (2006). Global civil society: Royal road or slippery path? Voluntas, 17(4), 325-332. 